\title{
Symptoms related to the visual system in migraine [version 1;
}

\section{peer review: 2 approved]}

\author{
Robin M. van Dongen (iD), Joost Haan ${ }^{1,2}$
}

${ }^{1}$ Department of Neurology, Leiden University Medical Centre, Albinusdreef 2, 2333 ZA, Leiden, The Netherlands

2Department of Neurology, Alrijne Ziekenhuis, Simon Smitweg 1, 2353 GA, Leiderdorp, The Netherlands

V1 First published: 30 Jul 2019, 8(F1000 Faculty Rev):1219

https://doi.org/10.12688/f1000research.18768.1

Latest published: 30 Jul 2019, 8(F1000 Faculty Rev):1219

https://doi.org/10.12688/f1000research.18768.1

\section{Abstract}

Migraine is a common headache disorder characterized by oftensevere headaches that may be preceded or accompanied by a variety of visual symptoms. Although a typical migraine aura is not difficult to diagnose, patients with migraine may report several other visual symptoms, such as prolonged or otherwise atypical auras, "visual blurring", "retinal migraine", "ophthalmoplegic migraine", photophobia, palinopsia, and "visual snow". Here, we provide a short overview of these symptoms and what is known about the relationship with migraine pathophysiology. For some symptoms, the association with migraine is still debated; for other symptoms, recent studies indicate that migraine mechanisms play a role.

\section{Keywords}

migraine aura, prolonged aura, persistent aura, retinal migraine, ophthalmoplegic migraine, photophobia, palinopsia, visual snow

\section{Open Peer Review}

Approval Status

1 2

version 1

30 Jul 2019

Faculty Reviews are review articles written by the prestigious Members of Faculty Opinions. The articles are commissioned and peer reviewed before publication to ensure that the final, published version is comprehensive and accessible. The reviewers who approved the final version are listed with their names and affiliations.

1. Christoph J. Schankin, University of Bern, Bern, Switzerland

2. Andrew Charles, David Geffen School of Medicine at the University of California, Los Angeles, USA

Any comments on the article can be found at the end of the article. 
Corresponding author: Robin M. van Dongen (r.m.van_dongen@lumc.nl)

Author roles: van Dongen RM: Conceptualization, Writing - Original Draft Preparation, Writing - Review \& Editing; Haan J: Conceptualization, Writing - Review \& Editing

Competing interests: No competing interests were disclosed.

Grant information: The author(s) declared that no grants were involved in supporting this work.

Copyright: ( 2019 van Dongen RM and Haan J. This is an open access article distributed under the terms of the Creative Commons Attribution License, which permits unrestricted use, distribution, and reproduction in any medium, provided the original work is properly cited.

How to cite this article: van Dongen RM and Haan J. Symptoms related to the visual system in migraine [version 1; peer review: 2 approved] F1000Research 2019, 8(F1000 Faculty Rev):1219 https://doi.org/10.12688/f1000research.18768.1

First published: 30 Jul 2019, 8(F1000 Faculty Rev):1219 https://doi.org/10.12688/f1000research.18768.1 


\section{Introduction}

Symptoms related to the visual system are common in migraine, a neurovascular brain disorder characterized by episodes of often-severe headache lasting between 4 hours and 3 days ${ }^{1}$. In almost one third of patients with migraine, the headache is preceded by a visual aura $^{2}$ but there are several other visual symptoms related to migraine. The purpose of this narrative review is to provide a brief overview of these visual symptoms. Because migraine prevalence is high-lifetime prevalences are $33 \%$ in women and $13 \%$ in men ${ }^{2}$ - many physicians, especially general practitioners, neurologists, and ophthalmologists, will see patients with migraine. First, as background, the typical migraine aura is discussed, followed by the differential diagnosis of atypical auras. Next, visual symptoms other than migraine aura are reviewed: photophobia, palinopsia, and visual snow.

\section{Typical visual migraine aura}

In its most typical form, a visual aura begins with a "scintillating scotoma", a small blind spot with a flickering, brightly colored, and typically jagged front-the so-called fortification spectrum - that generally expands in a $\mathrm{C}$-shape to one side of the visual field (Figure 1) 1 1,3. The expansion is gradual and lasts between 5 and 60 minutes. ${ }^{1}$. These visual symptoms are fully reversible and should not be accounted for by another disorder,

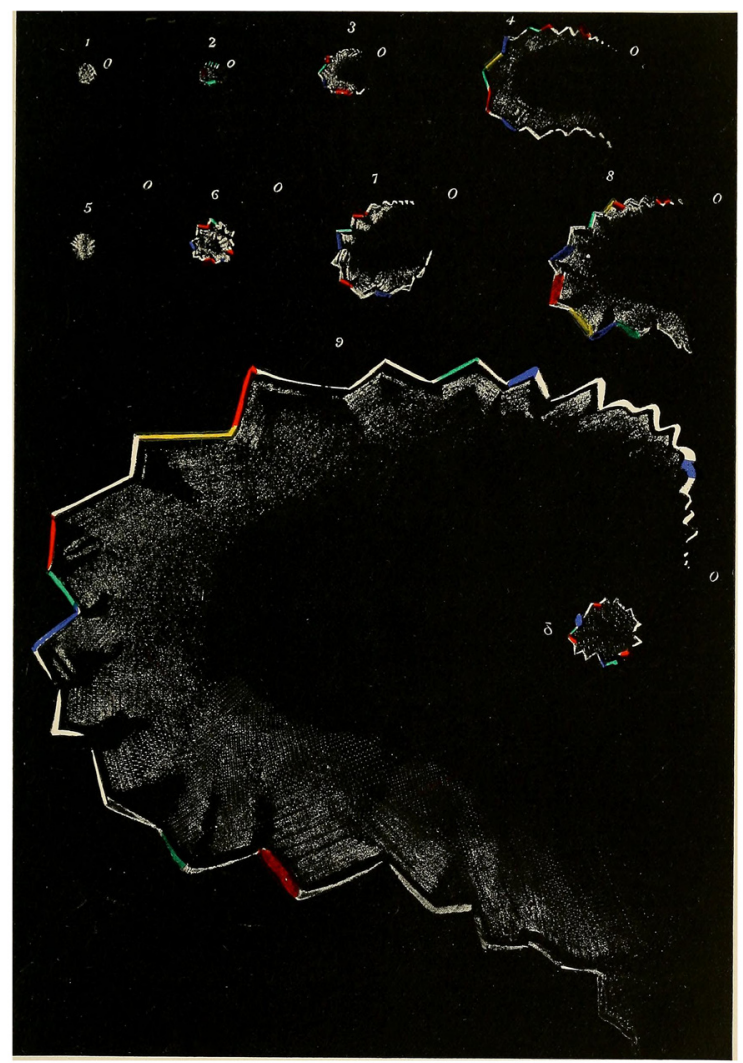

Figure 1. Example of a migraine aura. This picture illustrates the typical gradual expansion of a migraine aura along with the characteristic fortification spectrum. according to the third edition of the International Classification of Headache Disorders ${ }^{1}$. The positive symptoms often take shapes other than a classic fortification spectrum. Patients commonly report that the aura starts with light flashes or balls of light that gradually expand across the visual field ${ }^{4,5}$. Furthermore, positive symptoms do not have to occur; patients can also report that the scotoma (that is, the blind spot or the hole in the visual field) has no colors or jagged lines. When patients close their eyes, the positive features of an aura remain visible. Besides having visual symptoms, patients may experience sensory symptoms, speech problems, and sometimes motor symptoms during their auras ${ }^{1}$. If a person has had two attacks fulfilling criteria for migraine with aura, he or she is classified as a migraine with aura patient ${ }^{1}$. If a person has only attacks without aura, he or she is classified as migrainewithout-aura. Migraine with aura patients can still have attacks without aura. In a general-population study, median attack frequency was 12 attacks per year and $25 \%$ of patients with migraine had at least two attacks per month ${ }^{2}$.

Gradual expansion is considered the most typical feature of a migraine aura ${ }^{1}$. This corresponds with the suspected underlying pathophysiological mechanism called "cortical spreading depolarization" (CSD): a wave of intense neuronal and glial depolarization that is followed by neuronal depression. Preclinical and clinical studies suggest that the velocity of CSD through the occipital cortex is in line with the velocity of the visual spread observed by patients ${ }^{6-8}$. Patients can report a classic cascade in aura symptoms: the aura starts with visual symptoms and is followed by sensory symptoms, aphasia, and sometimes motor problems 9 . It is believed that in these cases the CSD expands from the occipital cortex to the motor cortex ${ }^{10}$. However, a prospective diary study showed that in $34 \%$ of patients the aura symptoms start simultaneously, suggesting that CSD may also start in a non-symptomatic brain area and reach two cortical areas at about the same time ${ }^{5,11}$. Sometimes patients report complex visual phenomena during their auras, such as distortions of observed body parts (for example, disproportionately large ears, sometimes referred to as the Alice in Wonderland syndrome) or visual splitting (one half of the observed face shifts upwards or downwards $)^{3,12,13}$. This suggests that more complex processes of visual perception, involving orientation and size, can also be altered during migraine attacks. Additionally, patients often report that during migraine auras their vision is "blurred" or "foggy" or that they see "heat waves". In the diary study, this was registered in $33 \%$ of auras 5 . However, information on gradual expansion was not collected. Furthermore, these symptoms have not been prospectively studied in migraine without aura patients. Therefore, there is still discussion about whether these symptoms are part of the aura spectrum.

In most patients, the aura is followed by a migraine headache. Typically, the headache starts after the aura has ended, although the headache can also start during or-in rare cases-before the aura ${ }^{5,9,14}$. In a minority of attacks, the aura is not followed by headache $e^{4,9}$ and this classically occurs in elderly patients and is often referred to as "late-life migraine accompaniments" ${ }^{\prime 15}$. 
Current acute migraine medication is able to treat the headache only and has no effect on the auras. Preventive drugs such as betablockers, candesartan, topiramate, valproate, and amitriptyline and nortriptyline are generally considered when patients have an average of more than two attacks per month. When successful, the auras can also be prevented. For patients with frequent auras, lamotrigine can also be tried ${ }^{16}$.

\section{Atypical visual migraine auras}

Atypical auras are important to identify because of the differential diagnosis with other diseases. First, migraine auras can mimic stroke because of the homonymous visual field defects or additional focal symptoms ${ }^{17}$. However, in migraine aura, symptoms gradually develop whereas in stroke they are often maximal from the start. Furthermore, classic aura features (colors and zig-zag lines) are generally not present in stroke ${ }^{18}$. Nonetheless, it can be hard to discriminate between the two diagnoses and other clinical factors such as age and cardiovascular risk factors should be taken into account. When the aforementioned "late-life migraine accompaniments" in an elderly patient are considered, secondary causes such as cerebral amyloid angiopathy should also be excluded. Amyloid spells (that is, transient focal neurological episodes caused by superficial cortical siderosis) can mimic migraine auras ${ }^{19}$.

Second, occipital epilepsy can also present with visual symptoms followed by headache but without the characteristic motor seizures. Classically, patients describe these symptoms as colored phosphenes ${ }^{3}$, although phosphenes can also be reported as aura symptoms by patients with migraine ${ }^{20}$. However, visual symptoms in epilepsy generally last shorter than 5 minutes and often start in the periphery of one temporal visual field whereas in migraine the auras generally start more to the center and expand to the periphery ${ }^{20}$. These criteria are not specific and sometimes electro-encephalography recordings could help in diagnosing occipital seizures. The following entities have been described as variants of migraine aura, although the actual relationship with migraine has been criticized for some of them.

\section{Prolonged and persistent aura}

In migraine, visual auras can last longer than the classic 60 minutes that is defined by the International Classification of Headache Disorders $^{21,22}$. In one diary study, $26.4 \%$ of patients had a visual aura, a sensory aura, or speech problems that lasted longer than 60 minutes $^{22}$. This is often referred to as "prolonged aura". However, visual auras lasting longer than 2 hours are considered rare and require additional investigation since they can be associated with cerebral infarction. If the aura is typical of previous auras (except in its duration) and there are imaging signs of ischemic infarction in the relevant brain area the term "migrainous infarction" is used to classify the infarct, but only if other causes of stroke are ruled out. Most cases of migrainous infarction are of cortical origin, suggesting that CSD could play a role; however, this could be confounding by indication since cortical infarcts are more likely to be classified as migrainous whereas subcortical infarcts may be attributed to a different cause $\mathrm{e}^{23-25}$. There is still debate on whether increased prevalence of patent foramen ovale in patients with migraine could play a role as well ${ }^{23,26}$.

If infarction and other causes of binocular visual disturbances are excluded and aura symptoms last longer than 1 week, the term "persistent aura without infarction" is used ${ }^{1}$. This is very rare. Symptoms can last months to years. Evidence on treatment is limited, lamotrigine is recommended on the basis of case series $^{27}$, and in one randomized controlled trial intranasal use of ketamine in patients with prolonged auras limited the aura severity but not the duration ${ }^{28}$.

\section{Migraine aura status}

Some patients with migraine with aura may experience a sudden and large increase in the frequency of their auras, typically without headache. If at least three auras occur over a period of 3 days, the term "migraine aura status" is used ${ }^{1}$. However, this diagnosis requires that secondary causes, including occipital infarction, arterial dissection, reversible cerebral vasoconstriction syndrome, and posterior reversible encephalopathy syndrome, be excluded ${ }^{1,29}$. Retrospective studies indicate that a migraine aura status is rare ${ }^{30,31}$. Aura frequency can spontaneously normalize within a few weeks, but acetazolamide ${ }^{32}$ or valproate ${ }^{31}$ could aid in this process and prevent new episodes, although evidence is limited to case reports.

\section{Retinal migraine}

The relevance of "retinal migraine" is still debated and unfortunately the term has been misused to describe visual auras, although these are binocular and homonymous and therefore of cortical origin. The term "retinal migraine" is reserved for monocular, fully reversible visual symptoms with at least two of the following criteria: the visual symptoms spread gradually during at least 5 minutes, last between 5 and 60 minutes, and are accompanied or followed within 60 minutes by headache'. Importantly, secondary causes of monocular visual disturbances should be excluded. Critics of retinal migraine argue that symptoms are not monocular in patients with this diagnosis but binocular and that patients were not properly instructed to discriminate between monocular and binocular symptoms ${ }^{33}$. Nonetheless, cases have been reported of recurrent, transient monocular visual disturbances followed by migraine headache in patients who were clearly instructed ${ }^{33}$. Proponents additionally argue that CSD can occur in the retina, although these studies are still limited to in vitro models ${ }^{34}$.

\section{Ophthalmoplegic migraine}

Some patients with migraine-in particular, children with migraine-reported transient double vision after a migraine attack. This ophthalmoplegia involved mostly the third cranial nerve. Therefore, the term "ophthalmoplegic migraine" was introduced. A prerequisite is that the ophthalmoplegia is preceded by a "migraine-like" headache in the prior four days. However, a literature review of published cases showed that one third of cases did not have a headache fulfilling migraine criteria $^{35}$. Furthermore, the time between the headache and the ophthalmoplegia could be as long as 14 days and there was 
often focal enhancement of the third cranial nerve on magnetic resonance imaging. It was therefore re-classified as "recurrent painful ophthalmoplegic neuropathy", and demyelization was suggested to play a role $\mathrm{e}^{1,35}$.

\section{Photophobia}

One of the main discriminating symptoms between migraine headache and other headache disorders is photophobia accompanying the headache, often occurring simultaneously with phonophobia ${ }^{1}$. Patients often report that the migraine headache is worsened by the presence of light and that they have to lie in the dark.

Therefore, photophobia is classically viewed as an ictal symptom. However, studies focusing on the premonitory phase-most often defined as the 48 hours before the migraine attack startsfound that up to $49 \%$ of patients already experienced photophobia before the headache developed ${ }^{36,37}$. Furthermore, patients report that they have light aversion on days not preceding or following a migraine attack $^{38}$. There is increasing evidence for this hypersensitivity to light. Interictally, patients with migraine have a lower light discomfort threshold than controls ${ }^{39}$. Additionally, many of them find patterns with high contrast more discomforting to look at ${ }^{38,39}$. This is supported by visual hyperexcitability studies using visual adaptation techniques ${ }^{40}$, visual evoked potentials ${ }^{41}$, and positron emission tomography (PET) brain imaging ${ }^{42}$ in patients with interictal migraine. Interestingly, migraine with aura patients reported more discomfort than migraine without aura patients, suggesting that visual hyperexcitability could play a more prominent role in the former ${ }^{39}$. This is in line with the hypothesis that migraine with aura patients have a lower threshold to experience a CSD. Although light stimulates nociceptive trigeminal neurons ${ }^{43}$, it is thought that central processes involving thalamus and visual cortex have a more important role ${ }^{44}$. There is also recent evidence from longitudinal studies that visual sensitivity already increases in the days preceding a migraine attack $^{45,46}$. Although these discoveries are promising, they have not led to therapeutic options for photophobia.

\section{Palinopsia}

Palinopsia is derived from the Greek words palin (again) and opsis (vision) and is used to describe perseveration of visual images. This can be experienced as seeing an afterimage of an object (after staring at an object and looking away) or as a series of images when an object is moving (Figure 2) ${ }^{47}$. Especially the former can be a normal physiological phenomenon when the stimulus was bright or there was a high contrast, and it results mostly in a negative afterimage: the afterimage is in complementary color. A positive afterimage, which has colors similar to those of the original image, is generally not considered physiological, although there is no strict cutoff in terms of frequency, duration, or other characteristics ${ }^{47}$. There is evidence that patients with migraine are more prone to palinopsia, although the number of studies is limited and methods differ ${ }^{45,48,49}$, complicating estimates on the prevalence of this symptom. In palinopsia, as in photophobia, it is thought that a central origin in the lateral geniculate nucleus of the posterior thalamus or visual cortex plays a role. Possibly altered sensory processing leading to palinopsia occurs primarily in the days preceding a migraine $\operatorname{attack}^{45}$.

\section{Visual snow}

Visual snow is characterized by the continuous presence of countless small dots in the entire visual field (Figure 3$)^{50}$. Patients often describe it as "TV static from a detuned analogue television" since the dots are flickering on and off $^{50}$. Although the severity of the snow can vary during the day, symptoms are never fully absent. Visual snow was not considered a separate entity until $2014^{50}$. Earlier reports often referred to the snow as a form of "persistent migraine aura", possibly because many patients have a history of migraine with aura ${ }^{27,51-55}$. However, in visual snow, the classic migraine features such as scintillating scotomas and fortification spectra are absent ${ }^{1,50,54}$. Furthermore, persistent migraine auras often start unilaterally and expand whereas patients with visual snow generally report that it started in the entire visual field and there was no spatial expansion ${ }^{50}$.

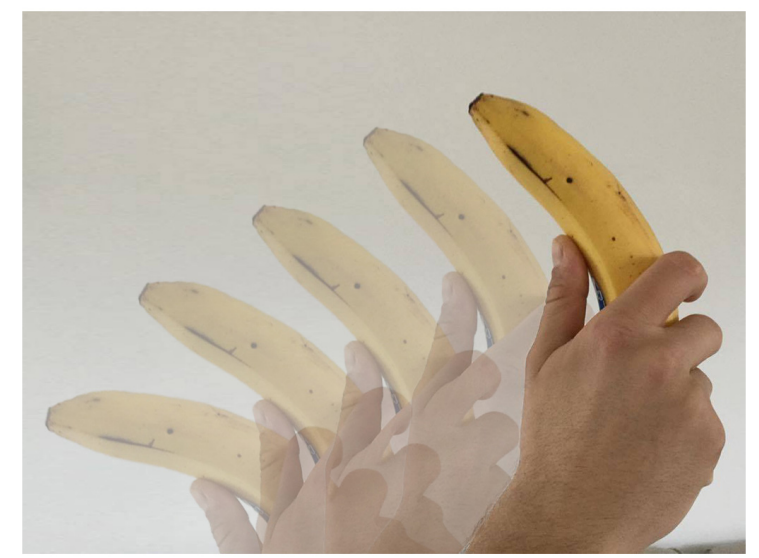

Figure 2. Example of palinopsia. An example of a moving object (the hand is moving from left to right) with perseverance of multiple images is shown.

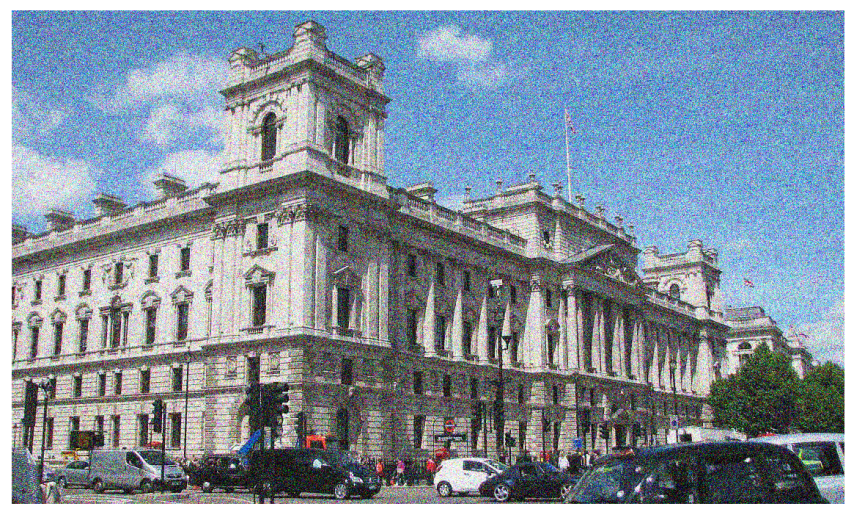

Figure 3. Example of visual snow. Patients with visual snow observe tiny dots in the entire visual field. The dots often resemble the "static" from a detuned analogue television because the dots "flicker on and off". Classically, the dots are black/gray on a white background and white on a black background, but colors may vary. 
Little is known about the epidemiology of visual snow ${ }^{50,56}$. Age of onset is often in the early twenties. In visual snow, in contrast to migraine, current data do not show an increased prevalence in females. Visual snow seems to be related to migraine: two case series found that between 47 and 59\% had a history of migraine and that the prevalence of migraine with aura was relatively high compared with that of migraine without aura $^{50,56}$. Furthermore, patients with migraine sometimes also report seeing visual snow, albeit transient and not continuous. In a prospective diary study, $8 \%$ of patients with migraine reported visual snow during their visual aura but not outside the aura ${ }^{5}$.

A diagnosis of visual snow is made after exclusion of secondary causes of pan-field visual disturbances, such as lesions in the visual pathways and retina. Nevertheless, ophthalmic and neurological examinations in patients with visual snow are generally normal ${ }^{50}$. Most patients report additional visual symptoms: palinopsia, enhanced entopic phenomena (excessive floaters or blue field entoptic phenomena and spontaneous photopsia), photophobia, and nyctalopia. Therefore, it was proposed that visual snow is part of a clinical syndrome ${ }^{50}$. The syndrome criteria were proposed for research purposes and have no current clinical consequence for diagnosis or prognosis. Visual snow has also been reported as a persistent visual effect after intake of illicit hallucinogenic drugs such as LSD and ecstasy ${ }^{57}$. However, since there are patients with visual snow who never used hallucinogenic $\operatorname{drugs}^{50}$ and since visual snow is also reported in children ${ }^{58}$, it seems that hallucinogenic drug use is not the only potential risk factor.

It is hypothesized that cortical hyperexcitability plays a role in visual snow as well. Theoretically, the visual disturbances can also be localized to bilateral retinal pathology; however, this seems unlikely since ophthalmological examinations and electro-retinograms are generally normal in patients with visual snow $^{50}$. Therefore, visual snow is generally considered a cortical problem. Indeed, there is some evidence that cortical excitability parameters are increased in patients with visual snow and without comorbid migraine. This has been tested by using visual tasks ${ }^{59}$ and visual-evoked potentials ${ }^{60}$, but findings still have to be replicated in larger studies. One study using $\left[{ }^{18} \mathrm{~F}\right]$-2-fluoro-2-de-oxyD-glucose PET showed hypermetabolism in the lingual gyrus, an area that modulates visual processing, in visual snow patients compared with healthy controls ${ }^{61}$. The same area was shown to be involved in previous migraine studies on photophobia ${ }^{42,62}$. However, because 14 out of 17 patients with visual snow also had comorbid migraine, it remains unknown whether this hypermetabolism is specific for visual snow ${ }^{61}$. Treatment of visual snow is limited to case reports and expert opinion. Lamotrigine may sometimes help $\mathrm{p}^{63,64}$.

\section{Conclusions}

The visual aura is the most typical form of visual disturbances in migraine but there are several other visual symptoms that people with migraine report. In this review, we have given a short clinical overview of these symptoms and what is known about the relationship with migraine pathophysiology. Although there are currently no specific therapeutic options focusing on visual symptoms, recent studies have begun to unravel some of the mechanisms that are involved.

\section{Grant information}

The author(s) declared that no grants were involved in supporting this work.
1. Headache Classification Committee of the International Headache Society (IHS) The International Classification of Headache Disorders, 3rd edition. Cephalalgia. 2018; 38(1): 1-211. PubMed Abstract | Publisher Full Text

2. Launer LJ, Terwindt GM, Ferrari MD: The prevalence and characteristics of migraine in a population-based cohort: The GEM study. Neurology. 1999; 53(3): 537-42.

PubMed Abstract | Publisher Full Text

3. Schott GD: Exploring the visual hallucinations of migraine aura: The tacit contribution of illustration. Brain. 2007; 130(Pt 6): 1690-703. PubMed Abstract | Publisher Full Text

4. Hansen JM, Goadsby PJ, Charles AC: Variability of clinical features in attacks of migraine with aura. Cephalalgia. 2016; 36(3): 216-24. PubMed Abstract | Publisher Full Text

5. F Viana M, Sances G, Linde $M$, et al.: Clinical features of migraine aura: Results from a prospective diary-aided study. Cephalalgia. 2017; 37(10): 979-89. PubMed Abstract | Publisher Full Text | F1000 Recommendation

6. Leão AAP: Spreading depression of activity in the cerebral cortex. J Neurophysiol. 1944; 7: 359-90.

Publisher Full Text

7. Hadjikhani N, Sanchez Del Rio M, Wu O, et al.: Mechanisms of migraine aura revealed by functional MRI in human visual cortex. Proc Natl Acad Sci U S A. 2001; 98(8): 4687-92.

PubMed Abstract | Publisher Full Text | Free Full Text

8. $\quad \mathrm{F}$ Hansen JM, Baca SM, VanValkenburgh $\mathrm{P}$, et al.: Distinctive anatomical and physiological features of migraine aura revealed by 18 years of recording. Brain. 2013; 136(Pt 12): 3589-95.

PubMed Abstract | Publisher Full Text | F1000 Recommendation

9. Russell MB, Olesen $\mathrm{J}$ : A nosographic analysis of the migraine aura in a general population. Brain. 1996; 119(Pt 2): 355-61. PubMed Abstract | Publisher Full Text

10. Ferrari MD, Klever RR, Terwindt GM, et al.: Migraine pathophysiology: lessons from mouse models and human genetics. Lancet Neurol. 2015; 14(1): 65-80. PubMed Abstract | Publisher Full Text

11. F Viana M, Linde $M$, Sances $G$, et al:: Migraine aura symptoms: Duration, succession and temporal relationship to headache. Cephalalgia. 2016; 36(5): 413-21.

PubMed Abstract | Publisher Full Text | F1000 Recommendation

12. Kew J, Wright A, Halligan PW: Somesthetic aura: The experience of "Alice in Wonderland". The Lancet. 1998; 351(9120): 1934.

PubMed Abstract | Publisher Full Text

13. Jürgens TP, Schulte LH, May A: Migraine trait symptoms in migraine with and 
without aura. Neurology. 2014; 82(16): 1416-24.

PubMed Abstract | Publisher Full Text

14. F Hansen JM, Lipton RB, Dodick DW, et al.: Migraine headache is present in the aura phase: A prospective study. Neurology. 2012; 79(20): 2044-9. PubMed Abstract | Publisher Full Text | Free Full Text | F1000 Recommendation

15. F Vongvaivanich $\mathrm{K}$, Lertakyamanee $\mathrm{P}$, Silberstein $\mathrm{SD}$, et al.: Late-life migraine accompaniments: A narrative review. Cephalalgia. 2014; 35(10): 894-911. PubMed Abstract | Publisher Full Text | F1000 Recommendation

16. Lampl C, Katsarava Z, Diener H-C, et al.: Lamotrigine reduces migraine aura and migraine attacks in patients with migraine with aura. $J$ Neurol Neurosurg Psychiatr. 2005; 76(12): 1730-2.

PubMed Abstract | Publisher Full Text | Free Full Text

17. Nadarajan V, Perry RJ, Johnson J, et al:: Transient ischaemic attacks: Mimics and chameleons. Pract Neurol. 2014; 14(1): 23-31. PubMed Abstract | Publisher Full Text | Free Full Text

18. F Lavallée PC, Cabrejo L, Labreuche J, et al.: Spectrum of transient visual symptoms in a transient ischemic attack cohort. Stroke. 2013; 44(12): 3312-7. PubMed Abstract | Publisher Full Text | F1000 Recommendation

19. Charidimou A, Peeters A, Fox Z, et al:: Spectrum of transient focal neurological episodes in cerebral amyloid angiopathy: Multicentre magnetic resonance imaging cohort study and meta-analysis. Stroke. 2012; 43(9): 2324-30. PubMed Abstract | Publisher Full Text

20. F Hartl E, Gonzalez-Victores JA, Rémi J, et al.: Visual Auras in Epilepsy and Migraine - An Analysis of Clinical Characteristics. Headache. 2017; 57(6): 908-16.

PubMed Abstract | Publisher Full Text | F1000 Recommendation

21. Viana $\mathrm{M}$, Sprenger $\mathrm{T}$, Andelova $\mathrm{M}$, et al:: The typical duration of migraine aura: $\mathbf{A}$ systematic review. Cephalalgia. 2013; 33(7): 483-90.

PubMed Abstract | Publisher Full Text

22. F Viana $M$, Sances $G$, Linde $M$, et al.: Prolonged migraine aura: New insights from a prospective diary-aided study. J Headache Pain. 2018; 19(1): 77. PubMed Abstract | Publisher Full Text | Free Full Text | F1000 Recommendation

23. F Wolf ME, Szabo K, Griebe M, et al: Clinical and MRI characteristics of acute migrainous infarction. Neurology. 2011; 76(22): 1911-7.

PubMed Abstract | Publisher Full Text | F1000 Recommendation

24. Laurell K, Artto V, Bendtsen L, et al.: Migrainous infarction: A Nordic multicenter study. Eur J Neurol. 2011; 18(10): 1220-6.

PubMed Abstract | Publisher Full Text

25. Lee MJ, Lee C, Chung C-S: The Migraine-Stroke Connection. J Stroke. 2016; 18(2): 146-56.

PubMed Abstract | Publisher Full Text | Free Full Text

26. F Koppen $\mathrm{H}$, Palm-Meinders IH, Mess WH, et al:: Systemic right-to-left shunts ischemic brain lesions, and persistent migraine activity. Neurology. 2016; 86(18): 1668-75.

PubMed Abstract | Publisher Full Text | Free Full Text | F1000 Recommendation

27. Thissen S, Vos IG, Schreuder TH, et al:: Persistent Migraine Aura: New Cases, a Literature Review, and Ideas About Pathophysiology. Headache. 2014; 54(8): 1290-309.

PubMed Abstract | Publisher Full Text

28. Afridi SK, Giffin NJ, Kaube $\mathrm{H}$, et al.: A randomized controlled trial of intranasal ketamine in migraine with prolonged aura. Neurology. 2013; 80(7): 642-7. PubMed Abstract | Publisher Full Text

29. $F$ Terrin A, Mainardi F, Maggioni F: The pathological spectrum behind migraine aura status: A case series. Neurol Sci. 2019; 40(4): 861-4. PubMed Abstract | Publisher Full Text | F1000 Recommendation

30. Beltramone $M$, Donnet $A$ : Status migrainosus and migraine aura status in a French tertiary-care center: An 11-year retrospective analysis. Cephalalgia. 2014; 34(8): 633-7.

PubMed Abstract | Publisher Full Text

31. João AA, Goucha TB, Martins IP: Aura status: A not so frequent aura. Cephalalgia. 2014; 34(14): 1150-62.

PubMed Abstract | Publisher Full Text

32. Haan J, Sluis $\mathrm{P}$, Sluis $\mathrm{LH}$, et al:: Acetazolamide treatment for migraine aura status. Neurology. 2000; 55(10): 1588-9. PubMed Abstract | Publisher Full Text

33. Hill DL, Daroff RB, Ducros A, et al.: Most cases labeled as "retinal migraine" are not migraine. J Neuroophthalmol. 2007; 27(1): 3-8. PubMed Abstract | Publisher Full Text

34. Wang M, Chazot PL, Ali S, et al:: Effects of NMDA receptor antagonists with different subtype selectivities on retinal spreading depression. Br J Pharmacol. 2012; 165(1): 235-44.

PubMed Abstract | Publisher Full Text | Free Full Text

35. Gelfand AA, Gelfand JM, Prabakhar P, et al:: Ophthalmoplegic "migraine" or recurrent ophthalmoplegic cranial neuropathy: new cases and a systematic review. J Child Neurol. 2012; 27(6): 759-66.

PubMed Abstract | Publisher Full Text | Free Full Text

36. Maniyar $\mathrm{FH}$, Sprenger $\mathrm{T}$, Monteith $\mathrm{T}$, et al:: The premonitory phase of migraine-what can we learn from it? Headache. 2015; 55(5): 609-20.

PubMed Abstract | Publisher Full Text

37. Giffin NJ, Ruggiero L, Lipton RB, et al.: Premonitory symptoms in migraine: an electronic diary study. Neurology. 2003; 60(6): 935-40.

PubMed Abstract | Publisher Full Text

38. Mulleners WM, Aurora SK, Chronicle EP, et al: Self-reported photophobic symptoms in migraineurs and controls are reliable and predict diagnostic category accurately. Headache. 2001; 41(1): 31-9. PubMed Abstract | Publisher Full Text

39. F Perenboom MJL, Zamanipoor Najafabadi AH, Zielman R, et al:: Quantifying visual allodynia across migraine subtypes: the Leiden Visual Sensitivity Scale. Pain. 2018; 159(11): 2375-82.

PubMed Abstract | Publisher Full Text | Free Full Text | F1000 Recommendation

40. Shepherd AJ: Increased visual after-effects following pattern adaptation in migraine: a lack of intracortical excitation? Brain. 2001; 124(Pt 11): 2310-8. PubMed Abstract | Publisher Full Text

41. Chen WT, Wang SJ, Fuh JL, et al:: Persistent ictal-like visual cortical excitability in chronic migraine. Pain. 2011; 152(2): 254-8. PubMed Abstract | Publisher Full Text

42. Boulloche N, Denuelle M, Payoux P, et al:: Photophobia in migraine: an interictal PET study of cortical hyperexcitability and its modulation by pain. $J$ Neurol Neurosurg Psychiatr. 2010; 81(9): 978-84. PubMed Abstract | Publisher Full Text

43. Okamoto $\mathrm{K}$, Tashiro A, Chang Z, et al.: Bright light activates a trigeminal nociceptive pathway. Pain. 2010; 149(2): 235-42.

PubMed Abstract | Publisher Full Text | Free Full Text

44. F Goadsby PJ, Holland PR, Martins-Oliveira M, et al.: Pathophysiology of Migraine: A Disorder of Sensory Processing. Physiol Rev. 2017; 97(2): 553-622. PubMed Abstract | Publisher Full Text | Free Full Text | F1000 Recommendation

45. $\mathrm{F}$ Luedtke $\mathrm{K}$, Schulte $\mathrm{LH}$, May A: Visual processing in migraineurs depends on the migraine cycle. Ann Neurol. 2019; 85(2): 280-3. PubMed Abstract | Publisher Full Text | F1000 Recommendation

46. F McKendrick AM, Chan YM, Vingrys AJ, et al.: Daily vision testing can expose the prodromal phase of migraine. Cephalalgia. $2018 ; \mathbf{3 8}(9)$ : $1575-8$ PubMed Abstract | Publisher Full Text | F1000 Recommendation

47. F Gersztenkorn D, Lee AG: Palinopsia revamped: a systematic review of the iterature. Surv Ophthalmol. 2015; 60(1): 1-35

PubMed Abstract | Publisher Full Text | F1000 Recommendation

48. Belcastro V, Cupini LM, Corbelli I, et al:: Palinopsia in patients with migraine: a case-control study. Cephalalgia. 2011; 31(9): 999-1004. PubMed Abstract | Publisher Full Text

49. $F$ Kalita J, Uniyal R, Bhoi SK: Is palinopsia in migraineurs an enhanced physiological phenomenon? Cephalalgia. 2016; 36(13): 1248-56. PublMed Abstract | Publisher Full Text | F1000 Recommendation

50. Schankin CJ, Maniyar FH, Digre KB, et al.: 'Visual snow' - a disorder distinct from persistent migraine aura. Brain. 2014; 137(Pt 5): 1419-28. PubMed Abstract | Publisher Full Text

51. Liu GT, Schatz NJ, Galetta SL, et al.: Persistent positive visual phenomena in migraine. Neurology, 1995; 45(4): 664-8. PubMed Abstract | Publisher Full Text

52. Rothrock JF: Successful treatment of persistent migraine aura with divalproex sodium. Neurology. 1997; 48(1): 261-2. PubMed Abstract | Publisher Full Text

53. Jäger HR, Giffin NJ, Goadsby PJ: Diffusion- and perfusion-weighted MR imaging in persistent migrainous visual disturbances. Cephalalgia. 2005; 25(5): 323-32. PubMed Abstract | Publisher Full Text

54. Wang YF, Fuh JL, Chen WT, et al:: The visual aura rating scale as an outcome predictor for persistent visual aura without infarction. Cephalalgia. 2008; 28(12): 1298-304

PubMed Abstract | Publisher Full Text

55. Chen WT, Lin YY, Fuh JL, et al:: Sustained visual cortex hyperexcitability in migraine with persistent visual aura. Brain. 2011; 134(Pt 8): 2387-95. PubMed Abstract | Publisher Full Text

56. F Lauschke JL, Plant GT, Fraser CL: Visual snow: A thalamocortical dysrhythmia of the visual pathway? J Clin Neurosci. 2016; 28: 123-7. PubMed Abstract | Publisher Full Text | F1000 Recommendation

57. Litjens RP, Brunt TM, Alderliefste GJ, et al.: Hallucinogen persisting perception disorder and the serotonergic system: a comprehensive review including new MDMA-related clinical cases. Eur Neuropsychopharmacol. 2014; 24(8): 1309-23. PubMed Abstract | Publisher Full Text

58. Simpson JC, Goadsby PJ, Prabhakar P: Positive persistent visual symptoms (visual snow) presenting as a migraine variant in a 12-year-old girl. Pediatr Neurol. 2013; 49(5): 361-3.

PubMed Abstract | Publisher Full Tex

59. F McKendrick AM, Chan YM, Tien M, et al.: Behavioral measures of cortical hyperexcitability assessed in people who experience visual snow. Neurology. 2017; 88(13): 1243-9.

PubMed Abstract | Publisher Full Text | F1000 Recommendation

60. F Eren O, Rauschel V, Ruscheweyh R, et al.: Evidence of dysfunction in the visual association cortex in visual snow syndrome. Ann Neurol. 2018; 84(6): 946-9.

PubMed Abstract | Publisher Full Text | F1000 Recommendation

61. Schankin CJ, Maniyar FH, Sprenger T, et al.: The relation between migraine, 
typical migraine aura and "visual snow". Headache. 2014; 54(6): 957-66. PubMed Abstract | Publisher Full Text

62. Denuelle M, Boulloche N, Payoux P, et al:: A PET study of photophobia during spontaneous migraine attacks. Neurology. 2011; 76(3): 213-8.

PubMed Abstract | Publisher Full Text

63. F Unal-Cevik I, Yildiz FG: Visual Snow in Migraine With Aura: Further
Characterization by Brain Imaging, Electrophysiology, and Treatment--Case Report. Headache. 2015; 55(10): 1436-41.

PubMed Abstract | Publisher Full Text | F1000 Recommendation

64. F White OB, Clough M, McKendrick AM, et al.: Visual Snow: Visual Misperception. J Neuroophthalmol. 2018; 38(4): 514-21.

PubMed Abstract | F1000 Recommendation 


\section{Open Peer Review}

\section{Current Peer Review Status:}

\section{Editorial Note on the Review Process}

Faculty Reviews are review articles written by the prestigious Members of Faculty Opinions. The articles are commissioned and peer reviewed before publication to ensure that the final, published version is comprehensive and accessible. The reviewers who approved the final version are listed with their names and affiliations.

\section{The reviewers who approved this article are:}

\section{Version 1}

\section{Andrew Charles}

UCLA Goldberg Migraine Program, David Geffen School of Medicine at the University of California, Los Angeles, USA Competing Interests: No competing interests were disclosed.

\section{Christoph J. Schankin}

Department of Neurology, Inselspital, Bern University Hospital, University of Bern, Bern, Switzerland Competing Interests: No competing interests were disclosed.

The benefits of publishing with F1000Research:

- Your article is published within days, with no editorial bias

- You can publish traditional articles, null/negative results, case reports, data notes and more

- The peer review process is transparent and collaborative

- Your article is indexed in PubMed after passing peer review

- Dedicated customer support at every stage

For pre-submission enquiries, contact research@f1000.com 